\title{
Urban Emissions and Regional Air Quality in India
}

\author{
Alexandra Karambelas ${ }^{1}$ \\ The Earth Institute, Columbia University, New York, NY
}

\begin{abstract}
Satellite observations from the Ozone Monitoring Instrument are used in support of model evaluation of seasonal average results from the U.S. Environmental Protection Agency (EPA) Community Multi-scale Air Quality (CMAQ) model. Model evaluation was conducted with the purpose of identifying regional biases in model output compared to tropospheric columns. Comparison with tropospheric column $\mathrm{NO}_{2}$, an anthropogenic indicator, reveal that there are uncertainties regarding the emissions inventory input to CMAQ. Results have implications for developing accurate model inputs to produce accurate model output for relevant health impact assessments, which are increasingly important with increasing population, urbanization, and pollution in the region.
\end{abstract}

\section{Introduction}

India's population exceeds 1.25 billion people, many of whom are exposed to exceedingly high ambient pollution, damaging human health and leading to illness and premature death. Indian cities rank among the most polluted in the world [World Health Organization, 2014], for instance the capital city, New Delhi, averages concentrations of $286 \mu \mathrm{g} / \mathrm{m}^{3}$ and $153 \mu \mathrm{g} / \mathrm{m}^{3}$ for $\mathrm{PM}_{10}$ and $\mathrm{PM}_{2.5}$ respectively ${ }^{2}$. Fine particulate matter, $\mathrm{PM}_{2.5}$, is of greatest health concern in India, and is a pollutant that is both directly emitted as well as formed from atmospheric

reactions involving nitrogen oxides $\left(\mathrm{NO}_{\mathrm{X}}\right)$ and sulfur dioxide $\left(\mathrm{SO}_{2}\right)$. Of increasing importance is surface level $\mathrm{O}_{3}$, formed from the reaction of $\mathrm{NO}_{\mathrm{X}}$ and volatile organic compounds (VOCs). Particulate ambient air pollution leads to 3.7 million deaths globally, with 570,000 occurring in India each year, and another 12,000 people estimated from gaseous $\mathrm{O}_{3}$ [Ghude et al., 2016]. Air pollution is a major health problem in India, affecting millions of residents and visitors.

India's pollution has grown coupled with the economy, population growth, urbanization, and motorization. Satellite data has shown that $\mathrm{NO}_{\mathrm{X}}$ and $\mathrm{SO}_{2}$ emissions have increased by $70 \%$ in recent years [ $\mathrm{Lu}$ and Streets, 2012; Lu et al., 2013], and surface observations from the CPCB show particulate concentrations have persistently increased in cities with 46 million people or more [ENVIS Centre on Control of Pollution, 2016]. Similarly, concentrations of $\mathrm{O}_{3}$ have been increasing at a rate of $1.3 \%$ annually in Delhi [Kumari et al., 2013]. Pollution in India does not go unnoticed, as recent efforts sought to reduce pollution in major cities including Delhi through transitions to liquid petroleum gas (LPG) for transportation [Bell et al., 2004; National Ambient Air Quality Monitoring, 2006], quantify pollution in Agra damaging to the Taj Mahal [Bergin et al., 2015], and assess source contributions in major cities across India [Guttikunda et al., 2014]. However, quantifiable efforts to improve air quality remain limited by weak enforcement power of

\footnotetext{
${ }^{1}$ This research was conducted at the University of Wisconsin-Madison under the supervision of Professor Tracey Holloway in the Center for Sustainability and the Global Environment with the support from the Wisconsin Space Grant Consortium Dr. Laurel Salton Clark Memorial Research Fellowship and the NASA Air Quality Applied Sciences Team. ${ }^{2}$ http://apps.who.int/gho/data/
} 
the Central Pollution Control Board and limitations in detailed air quality information in diverse regions across India.

This research examines the connections between energy, emissions, and air quality in India using a suite of air quality assessment tools and techniques. Here, we use vertical column densities of $\mathrm{NO}_{2}$ to evaluate regional air quality model performance in India, including comparing modeled with satellite-derived surface $\mathrm{NO}_{2}$. Similar tropospheric column evaluation for formaldehyde (HCHO), a VOC, can be found in the Supplemental Information. This research investigates the use of satellite observations and spatiotemporal trend analysis in support of model column evaluation. A combination of air quality tools is imperative to this research as models and satellite observations offer vast spatiotemporal coverage to ensure thorough evaluation of air quality conditions in India, a highly polluted, developing region. Additional trend analysis in satellite observations of nitrogen dioxide $\left(\mathrm{NO}_{2}\right), \mathrm{SO}_{2}$, and $\mathrm{HCHO}$ from the Ozone Monitoring Instrument (OMI) and aerosol optical depth (AOD) from the Moderate Resolution Imaging Spectroradiometer (MODIS) is presented in the Supplemental Information.

\subsection{Satellite Observations for Air Quality Analysis}

Enhanced spatial coverage by satellites fills in gaps left behind by surface observations. This supply of data is critical in regions like India, with spatial coverage mostly limited to urban areas and operational accuracy dissimilar across Indian states [ENVIS Centre on Control of Pollution, 2016]. Many studies on Indian air quality rely on satellite observations as a result of these biases and limited availability of ground-based monitor data across India, including $\mathrm{NO}_{2}$ from $\mathrm{OMI}$ aboard the Aura satellite [Lamsal et al., 2010; Ghude et al., 2013]. Satellite observations from OMI and other instruments have been previously used to evaluate emissions and surface concentrations [Lamsal et al., 2010; Lu and Streets, 2012; Lu et al., 2013; Streets et al., 2013], observe trends in air quality [Lamsal et al., 2013, 2015; Duncan et al., 2015; Krotkov et al., 2015], evaluate AOD for dust or anthropogenic pollution [King et al., 2003; Isakov et al., 2007; Zhao et al., 2010], and estimate $\mathrm{NO}_{\mathrm{X}}$ to VOC ratios in assessing $\mathrm{O}_{3}$ regimes [Jin and Holloway, 2015]. Limitations of satellite observations include temporal availability (i.e. once per day), and the fact that cloud or intense smoke coverage can obscure satellite imagery [Zhang et al., 2009; Muntaseer Billah Ibn Azkar et al., 2012]. Despite temporal and retrieval limitations, satellite observations provide a significant amount of data to evaluate a wide range of air quality phenomenon and circumstances.

\subsection{Satellite Observations Supporting Model Result Evaluation}

Satellite observations are an increasingly useful tool for air quality model analysis. Tropospheric column observations can be used to evaluate model performance in terms of relevant column output, examining emissions in a region, and drawing inferences for photochemical relationships among precursor species. They have been used to evaluate regional model results [Zhang et al., 2009; Muntaseer Billah Ibn Azkar et al., 2012; Kemball-Cook et al., 2015], in support of $\mathrm{O}_{3}$ source assessment [McDonald-Buller et al., 2011], and for biogenic contribution assessment [Carlton and Baker, 2011]. The availability and use of satellite retrievals of air pollutant for model evaluation is incredibly useful to assess model performance in between surface monitors, important for ruralregional conclusions. 
The Wisconsin Horizontal Interpolation Program for Satellites (WHIPS) allows simpler comparison between model results and satellite observations [Oberman et al., 2014]. Produced at the University of Wisconsin-Madison, WHIPS interpolates Level 2 satellite data for select atmospheric constituents to a use-specified model grid. This allows nearly one-to-one comparison between modeled and satellite tropospheric columns. WHIPS has been used previously for model evaluation in numerous air quality studies in the U.S. [Harkey et al., 2015; Kemball-Cook et al., 2015], and here WHIPS is used to process satellite data for air quality model evaluation in India.

Developing the capability of CMAQ, a policy-relevant regional air quality model, for answering air quality questions related to energy and emissions in India will be inherently helpful in future experiments isolating emission sector or airshed contributions to regional air quality. In this research validate the use of CMAQ with seasonal space-borne observation evaluation. Results are presented for simulations that include windblown dust, and implications and limitations of this modeling study are discussed.

\section{Data and Methods}

\subsection{Satellite Interpolation}

Space-based observations used for model evaluation are from OMI aboard the Aura satellite [National Aeronautics and Space Administration, 2012]. Tropospheric column observations include $\mathrm{NO}_{2}$ and $\mathrm{HCHO}$ (see Supplemental Information), indicative of urban combustion sources and a proxy for biogenic contributions, respectively. We assess tropospheric columns of $\mathrm{NO}_{2}$ to determine spatial consistencies between modeled and observed. Finally, we present surfacederived $\mathrm{NO}_{2}$ from $\mathrm{OMI}$ as a way to estimate surface concentrations from OMI.

Daily tropospheric column values were downloaded from the TEMIS database ${ }^{3}$ and NASAMirador ${ }^{4}$ respectively for the overpass time across India of approximately 2 PM local time in Level 2 data format for further processing in WHIPS. Downloaded data were processed through WHIPS, which regrids Level 2 processed satellite data to be consistent with a model grid format the user inputs, in our case one that is comparable with our CMAQ grid and domain of choice. Through WHIPS we are able to provide a one-to-one comparison between OMI observed columns and CMAQ columns once an averaging kernel has been applied to model data columns.

\subsection{Model Simulations from CMAQ}

Model simulations were conducted using CMAQ v5.0.1 at $36 \mathrm{~km}$ by $36 \mathrm{~km}$ over the Indian subcontinent and surrounding countries including parts of Afghanistan, Pakistan, China, Nepal, Bangladesh, and Bhutan $\left(5^{\circ} \mathrm{N}\right.$ to $40^{\circ} \mathrm{N}, 60^{\circ} \mathrm{E}$ to $\left.100^{\circ} \mathrm{E}\right)$. Model simulations are conducted for four seasonally representative months - January, April, July, and October-representing winter, premonsoon, monsoon, and post-monsoon fall respectively. The CMAQ model includes processes related to surface and upper level emissions, photolysis, gaseous and particulate chemistry,

\footnotetext{
${ }^{3}$ http://www.temis.nl/airpollution/no2col/no2regioomi_v2.php

${ }^{4} \mathrm{http}: / /$ mirador.gsfc.nasa.gov
} 
deposition, and dispersion across grid cells and 36 vertical layers in the troposphere up to about 150hPa [Byun and Schere, 2006]. Model specifications include the chemistry bond 05 (CB05) chemical mechanism [Yarwood et al., 2005], the AERO 6 aerosol mechanism, and the inclusion of windblown dust [Dong et al., 2015; Tong et al., 2015]. A detailed description of updates to the dust mechanism is included in the Supplemental Information.

CMAQ requires inputs including boundary and initial conditions, emissions, and meteorology. Boundary and initial conditions remain static for all simulations. Anthropogenic emissions for year 2010 are regridded to $36 \mathrm{~km}$ by $36 \mathrm{~km}$ from 0.5 degree by 0.5 degree output from the Greenhouse Gas-Air Pollution Interactions and Synergies (GAINS) Model. Anthropogenic emission sectors include energy combustion, domestic combustion, transportation, agriculture, extraction and removal of energy sources, area sources, and industrial sources. Meteorology for 2010 is simulated using the Weather Research and Forecasting (WRF) model v3.2 and Preprocessing System (WPS) and ERA-Interim reanalysis from the European Center for Medium-Range Weather Forecasting (ECMWF) [Dee et al., 2011]. WRF is used to interpolate 6- hour data to hourly data. Data from WRF is simulated using Grell cumulus parameterization [Grell and Devenyi, 2002] with 36 vertical sigma layers from the surface to approximately $150 \mathrm{hPa}$. Meteorological data was preprocessed for use in CMAQ with the Meteorology- Chemistry Interface Processor (MCIP). Gaseous and particulate concentrations from model output at the surface and tropospheric column are validated with available surface observations and satellite observations, including the comparison with NO2 columns presented here.

\section{Results}

\subsection{1 Tropospheric Column $\mathrm{NO}_{2}$}

Highest OMI $\mathrm{NO}_{2}$ column densities are found nearly year round stretching across northern India bordering the Himalayan Mountains, as well as in cities such as Delhi (northwest), Mumbai (southwest coast), and Kolkata (east) (Fig. 1a-d). Because of the heavy monsoon rains in July, filters removing cloud cover greater than $30 \%$ are more prevalent in July than in any other month, leading to more grid cells without data in July as compared to other months (Fig. 1c). Monthly variations show lowest $\mathrm{NO}_{2}$ column densities in July, representative of the monsoon season with greatest rainfall rates, and greatest vertical column densities in January as a result of lower rainfall, shallow boundary layer height, and thus reduced wind speeds (Fig. 1a). During winter, increased emissions from wintertime heating occur due to biomass burning in low-income urban and rural areas where biomass is the primary heating and cooking fuel. April exhibits consistent $\mathrm{NO}_{2}$ densities across much of India, with column totals peaking in northwestern India near Delhi. Relatively higher $\mathrm{NO}_{2}$ column densities in April (Fig. 1b) and October (Fig. 1d) are found in Delhi and industrial regions in the eastern part of the country. High-density $\mathrm{NO}_{2}$ tropospheric columns in these regions are colocated with emissions from aluminum manufacturing plants, located in Renukoot in the state of Uttar Pradesh and coal-fired power plants and industrial sources directly south in Korba in the state of Chattisgarh. Tropospheric column densities over Renukoot and Korba, with a population of about 350,000 and 315,000 people respectively, are often as large as column densities found over Delhi, a megacity with a population surpassing 12 million people. Industries in India are subject to minimal enforced emissions regulations, therefore OMI tropospheric columns detecting high $\mathrm{NO}_{2}$ densities in these regions are therefore unsurprising. 

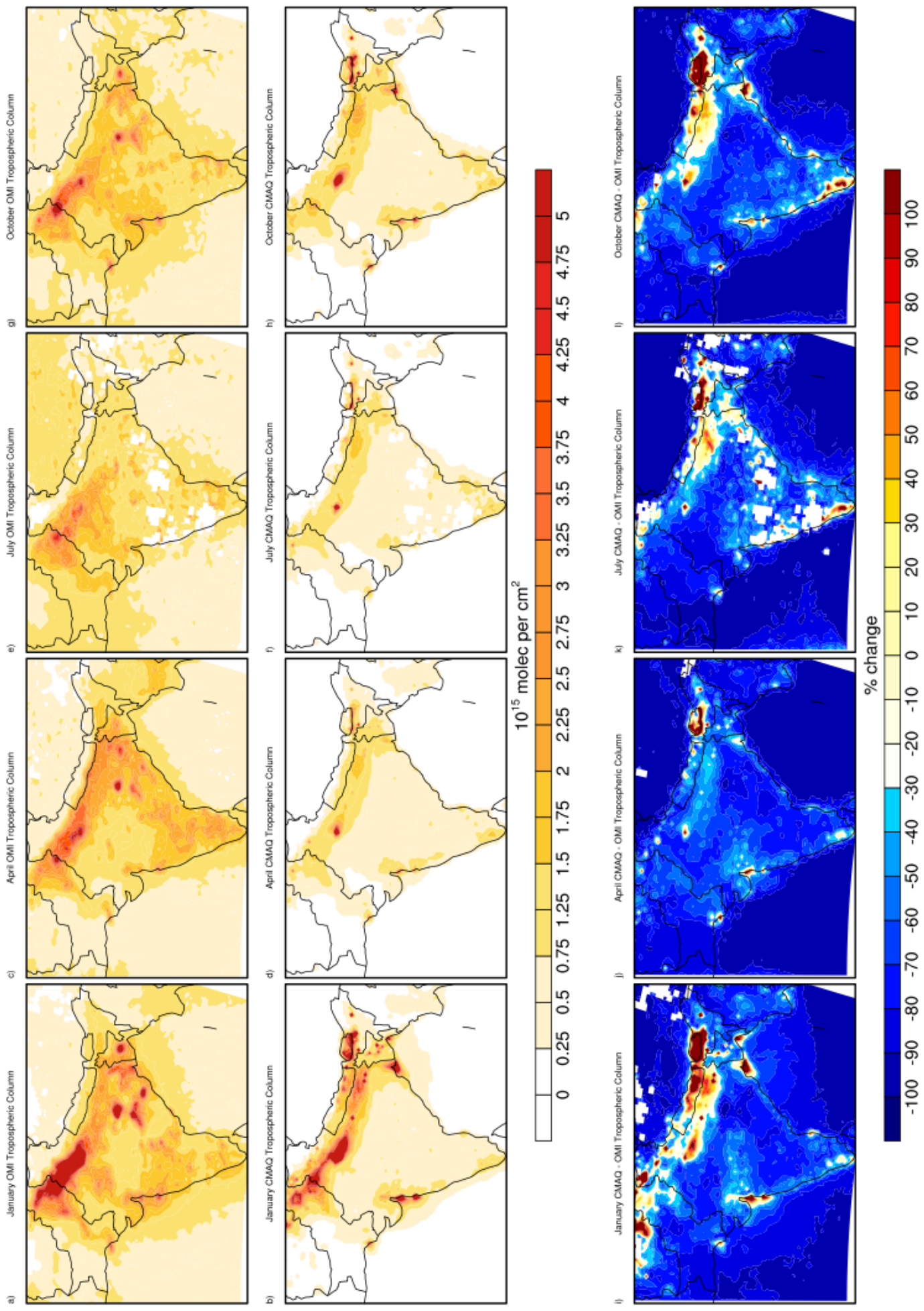

Fig. 1: Tropospheric column $\mathrm{NO}_{2}$ from OMI for (a) January, (b) April, (c) July, and (d) October, from CMAQ for (e) January, (f) April, (g) July, and (h) October, and the percent change between model and observed for (i) January, (j) April, (k) July, and (l) October. 
Comparative $\mathrm{NO}_{2}$ tropospheric column densities extracted from CMAQ tend to over-estimate column densities in urban regions, namely Delhi, and underestimate elsewhere across the country (Fig. 1e-h). In particular, regions of industry noted in the eastern part of India yield very miniscule modeled tropospheric column densities. Highest densities occur in January, coincident with the shallow boundary layer and low rainfall characteristic of wintertime meteorology (Figure 1e), and lowest in July due to high levels of mixing and monsoon rainfall (Fig. 1g). Column densities in Delhi tend to remain high despite high amounts of rainfall. In addition, CMAQ columns appear to overestimate $\mathrm{NO}_{2}$ in the urban south (e.g. Surat and Mumbai, along the west coast) and underestimate $\mathrm{NO}_{2}$ across rural regions. Other regions where CMAQ seems to overestimate $\mathrm{NO}_{2}$ tropospheric columns occur in parts of Nepal (January) and Bhutan (all seasons). Reasons for discrepancies are likely due to difficulties in accurately accounting for emissions in these regions coupled with modeling the topography of the Himalayas. Despite differences in magnitude, monthly variations in modeled $\mathrm{NO}_{2}$ column densities tend to mimic those observed. However, modeled tropospheric columns are only indicative of a response to meteorology, because emissions in our simulations do not vary seasonally. Across all seasons, modeled tropospheric columns of $\mathrm{NO}_{2}$ are overestimated in urban areas and underestimated everywhere else regionally (Fig. 1i-1).

\begin{tabular}{|c|r|r|r|r|r|}
\hline $\mathbf{N O}_{2}$ & \multicolumn{1}{|c|}{ Annual } & \multicolumn{1}{c|}{ January } & \multicolumn{1}{c|}{ April } & \multicolumn{1}{c|}{ July } & \multicolumn{1}{c|}{ October } \\
\hline $\mathbf{r}^{\mathbf{2}}$ & 0.42 & 0.45 & 0.55 & 0.39 & 0.41 \\
\hline NMB & $-65.8 \%$ & $-63.5 \%$ & $-76.1 \%$ & $-80.9 \%$ & $-70.0 \%$ \\
\hline NME & $77.0 \%$ & $79.7 \%$ & $78.6 \%$ & $84.1 \%$ & $78.4 \%$ \\
\hline
\end{tabular}

Table 1: Correlations, normalized mean biases, and normalized mean errors for CMAQ and OMI $\mathrm{NO}_{2}$ tropospheric columns for January, April, July, and October monthly averages. Data points are limited, with a maximum of 123 time steps assuming one overpass for each day. Correlations differ across seasons due to meteorology or changes in non-anthropogenic emission inventories. A land mask has been applied to both datasets, and statistics are only taken for grid cells with land cover.

Correlations between OMI and CMAQ tropospheric $\mathrm{NO}_{2}$ columns are moderate, at $\mathrm{r}^{2}=0.42$ across all four seasonally representative simulations (Table 1). Correlations are most positive in April and weakest in July. Poor correlations in July are likely a result of the monsoon season and a low precipitation bias in MCIP, resulting in greater modeled pollution. Annual average normalized mean bias is large and negative, with the greatest low bias in July (average: $-65.8 \%$, July: -80.9\%), and as such annual average normalize mean error remains large at $77.0 \%$. In all four simulations, model tropospheric densities over Delhi, Mumbai, and other highly populated regions exhibit high biases compared to OMI tropospheric columns by more than several molecules $/ \mathrm{cm}^{2}$. Outside of major Indian cities in rural India, model $\mathrm{NO}_{2}$ columns exhibit extreme low biases compared with satellite-observed columns. From (Fig.1) we saw that much of the model domain exhibited a low bias in comparison to OMI observations, thus low model values in rural areas dominate domain average statistics. 


\subsection{Satellite-Derived Surface $\mathrm{NO}_{2}$ Concentrations}

From comparing OMI tropospheric $\mathrm{NO}_{2}$ columns and surface observations of $\mathrm{NO}_{2}$ at various locations across India (not shown), it is apparent that CMAQ exhibits a domain average low bias yet has a consistent high bias in urban areas. Much of the sub-continent remains unmonitored, but we can estimate satellite-derived surface concentrations for surface comparison using OMI and CMAQ tropospheric columns and CMAQ surface concentrations. Here, we use an identical equation structure to estimate surface observations as detected by OMI:

$$
\mathrm{NO}_{2} \text { Surface }_{\mathrm{OMI}}=\frac{\mathrm{NO}_{2} \text { Surface }_{C M A Q}}{\mathrm{NO}_{2} \text { Column }_{C M A Q}} * \mathrm{NO}_{2} \text { Column }_{O M I}
$$

Eq. 2:

We compare annual average surface $\mathrm{NO}_{2}$ concentration from CMAQ at OMI overpass time (2PM, Fig. 1a), and surface-estimated $\mathrm{OMI} \mathrm{NO}_{2}$ (Fig. 1b). Average surface $\mathrm{NO}_{2}$ concentrations at overpass time display a similar spatial distribution to annual average modeled surface $\mathrm{NO}_{2}$, but concentrations are lower across the country, including in Mumbai, Kolkata, and Delhi due to higher afternoon chemical reaction of $\mathrm{NO}_{2}$ and VOCs to form $\mathrm{O}_{3}$. Model concentrations at the $2 \mathrm{PM}$ overpass time are generally lower than surface-estimated $\mathrm{NO}_{2}$ from $\mathrm{OMI}$ tropospheric columns. Across most of India, OMI-derived surface concentrations exceed 1- 2 ppb, with high instances of urban and industrial regions exposed. OMI-estimated surface concentrations in the industrialized east exhibit $\mathrm{NO}_{2}$ surface concentrations more than three times modeled surface concentrations, from less than $0.5 \mathrm{ppb}$ estimated by CMAQ to more than $5 \mathrm{ppb}$ estimated by OMI at the surface. Domain average surface concentrations differ by $0.7 \mathrm{ppb}$, with average $\mathrm{NO}_{2}$ from CMAQ of $0.3 \mathrm{ppb}$ and average estimated $\mathrm{NO}_{2}$ from OMI of $1.0 \mathrm{ppb}$. Vast differences suggest there are significant underestimates of $\mathrm{NO}_{\mathrm{x}}$ species in the emissions inventories used in these simulations, especially across southern India.

\section{Summary and Conclusions}

This report presents statistical evaluation of modeled tropospheric columns by using $\mathrm{OMI} \mathrm{NO}_{2}$ tropospheric columns to characterize and evaluate performance under different meteorological conditions from the summer monsoon to winter dry season. Model simulations with enhanced windblown dust were evaluated with satellite observations to characterize performance of $\mathrm{NO}_{2}$ as a result of including the dust parameterization. Evaluation techniques included satellite tropospheric column observations and deriving satellite-estimated surface concentrations of $\mathrm{NO}_{2}$. Although some global and regional models have been used to model air quality in south Asia, this is one of the earliest applications of CMAQ to simulate and evaluate modeled air quality in India. We find that model biases compared to $\mathrm{OMI} \mathrm{NO}_{2}$ tropospheric column densities are quite large and negative in non-urban regions across the domain. Large biases may exist because of limitations in spatial distribution and quantity of $\mathrm{NO}_{X}$ emissions input into $\mathrm{CMAQ}$, including the fact that our simulations do not include $\mathrm{NO}_{\mathrm{X}}$ emissions from lightning. India, in the tropics, is prone to a significant number of annual lightning flashes across the entire country, including regions which already exhibit a high bias compared to OMI [Cecil et al., 2014]. However, regional average low biases between OMI $\mathrm{NO}_{2}$ tropospheric columns and regional and global chemistry models are common [Allen et al., 2012; Kemball-Cook et al., 2015]. In the case of this study, we find that low biases exist in many 
non-urban regions across India between modeled and $\mathrm{OMI} \mathrm{NO}$, column densities as well as between modeled, while modeled columns and surface concentrations at Delhi and other urban locations exhibit a high bias. Surface $\mathrm{NO}_{2}$ concentrations estimated from OMI tropospheric columns indicate that CMAQ concentrations are low by an average of $0.7 \mathrm{ppb}$ across the domain. From this, we can attribute these biases to two factors: lack of upper tropospheric $\mathrm{NO}_{\mathrm{X}}$ emissions from lightning particularly during the monsoon and periods of active convection, and an underestimate of rural $\mathrm{NO}_{\mathrm{X}}$ emissions in our inventory.

Model biases are lowest in northern India, where the population and emissions input into CMAQ are largest. Uncertainties in emissions inventories are commonplace across developing regions where much of the country's energy may be derived from unaccountable biomass burning, industries and power plants begin operating rapidly, private transportation is burgeoning, and direct emissions from easily measureable stationary sources largely remain unquantified because the industries themselves are given that task. These are inherent problems that require addressing, however they were will require significant effort to improve. In the present study, anthropogenic emissions are divvied up evenly into days, and allocated during typical emitting hours per sector.More detailed temporal emissions distributions have been quantified, mostly in Delhi [Guttikunda and Calori, 2013; Pant et al., 2015], and season specific emissions have been measured across urban areas using tracers in source apportionment studies [Chowdhury et al., 2007; Behera and Sharma, 2010; Ghosh et al., 2014]. Currently, monthly variations in ambient air quality are the result of meteorological impacts, where greatest pollution was evident in the winter, when PBL heights are shallow, and lowest during the monsoon season due to pollution "rain out." Implementing seasonally varying anthropogenic emissions will likely have a significant impact on pollutant concentrations and tropospheric column comparisons with satellite observations.
Annual Average CMAQ Surface $\mathrm{NO}_{2}$ at OMI Overpass

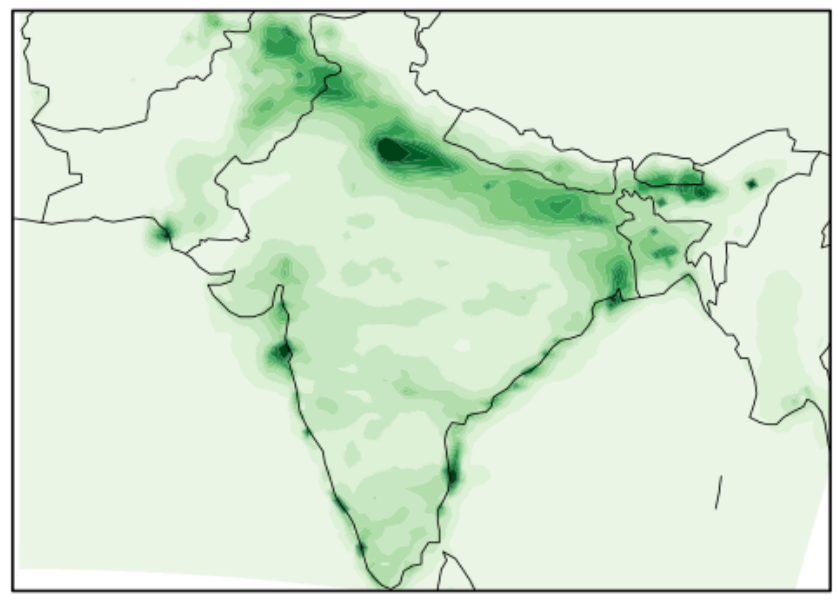

Annual Average OMI Estimated Surface $\mathrm{NO}_{2}$

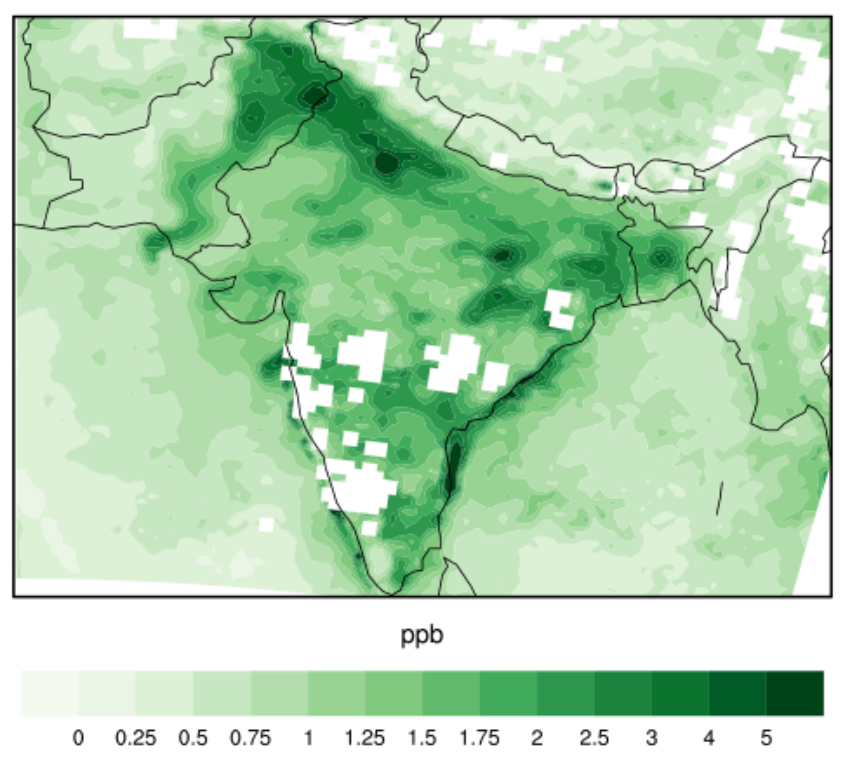

Fig. 5: Annual average surface $\mathrm{NO}_{2}$ from CMAQ at overpass time (top), and OMI-derived surface $\mathrm{NO}_{2}$ concentrations (bottom). Serious discrepancies exist across much of the subcontinent, especially in central India and noticeable regions on industry in the east. Differences can largely be attributed to emissions inventory shortcomings. The average CMAQ surface $\mathrm{NO}_{2}$ at overpass time is $0.3 \mathrm{ppb}$ and the average OMI- derived surface $\mathrm{NO}_{2}$ concentration is $1.02 \mathrm{ppb}$. 
Adding such seasonality to anthropogenic emissions will likely improve comparison with satellite observations.

References

Allen, D. J., et al.(2012), Impact of lightning-NO on eastern United States photochemistry during the summer of 2006 as determined using the CMAQ model, Atmos. Chem. Phys., 12(4), 1737-1758, doi:10.5194/acp-12- 1737-2012.

Behera, S. N., and M. Sharma (2010), Reconstructing Primary and Secondary Components of PM 2.5 Composition for an Urban Atmosphere, Aerosol Sci. Technol., 44(11), 983-992, doi:10.1080/02786826.2010.504245.

Bell, R. G., et al. (2004), Clearing the Air: How Delhi Broke the Logjam on Air Quality Reforms, Environ. Sci.Policy Sustain. Dev., doi:10.1080/00139150409604376.

Bergin, M. H., et al. (2015), The discoloration of the Taj Mahal due to particulate carbon and dust deposition, Environ. Sci. Technol., 49(2), 808-812, doi:10.1021/es504005q.

Byun, D., and K. L. Schere (2006), Review of the Governing Equations, Computational Algorithms, and Other Components of the Models-3 Community Multiscale Air Quality (CMAQ) Modeling System, Appl. Mech. Rev., 59(2), 51, doi:10.1115/1.2128636.

Carlton, A. G., and K. R. Baker (2011), Photochemical modeling of the Ozark isoprene volcano: MEGAN, BEIS, and their impacts on air quality predictions., Env. Sci. Tech., 45(10), 4438-45, doi:10.1021/es200050x.

Cecil, D. J., D. E. Buechler, and R. J. Blakeslee (2014), Gridded lightning climatology from TRMM-LIS and OTD: Dataset description, Atmos. Res., 135-136, 404-414, doi:10.1016/j.atmosres.2012.06.028.

Chowdhury, Z., et al. (2007), Speciation of ambient fine organic carbon particles and source apportionment of PM2.5 in Indian cities, J. Geo. Res. Atmos., 112(15), doi:10.1029/2007JD008386.

Dee, D. P. et al. (2011), The ERA-Interim reanalysis: Configuration and performance of the data assimilation system, $Q . J$. $R$. Meteorol. Soc., 137(656), 553-597, doi:10.1002/qj.828.

Dong, X., et al. (2015), Model development of dust emission and heterogeneous chemistry within the Community Multiscale Air Quality modeling system and its application over East Asia, Atmos. Chem. Phys. Discuss., 15(24), 35591-35643, doi:10.5194/acpd-15-35591-2015.

Duncan, B. N., et al. (2015), A space-based high-resolution view of notable changes in urban NOx pollution around the world (2005-2014), J. Geophys. Res. Atmos., 121, 976-996, doi:10.1002/2014JD022963. Received.

ENVIS Centre on Control of Pollution (2016), Air Quality: National Air Quaity Monitoring Programme (NAMP), Available from: http://cpcbenvis.nic.in/air_pollution_main.html.

Ghosh, S. et al. (2014), Chemical characterization of summertime dust events at Kanpur: Insight into the sources and level of mixing with anthropogenic emissions, Aerosol Air Qual. Res., 14(3), 879-891, doi:10.4209/aaqr.2013.07.0240.

Ghude, S. D., et al. (2013), Satellite constraints of nitrogen oxide (NOx) emissions from India based on OMI observations and WRF-Chem simulations, Geophys. Res. Lett., 40(x), 423-428, doi:10.1029/2012GL053926.

Ghude, S. D., et al. (2016), Premature mortality in India due to PM2.5 and ozone exposure, Geophys. Res. Lett., 43, 4650-4658, doi:10.1002/2013GL058740.Received.

Grell, G. A., and D. Devenyi (2002), A generalized approach to parameterizing convection combining ensemble and data assimilation techniques, Geophyiscal Res. Lett., 29(14), 10-13.

Guttikunda, S. K., G. Calori (2013), A GIS based emissions inventory at $1 \mathrm{~km} \times 1 \mathrm{~km}$ spatial resolution for air pollution analysis in Delhi, India, Atm. Env., 67, 101-11, doi:10.1016/j.atmosenv.2012.10.040.

Guttikunda, S. K., R. Goel, and P. Pant (2014), Nature of air pollution, emission sources, and management in the Indian cities, Atmos. Environ., 95, 501-10, doi:10.1016/j.atmosenv.2014.07.006.

Harkey, M., T. Holloway, J. Oberman, and E. Scotty (2015), An evaluation of CMAQ NO2 using observed chemistry-meteorology correlations, J. Geophys. Res. Atmos., (2), 1-19, doi:10.1002/2014JD022994.Received.

Isakov, V. et al. (2007), Estimating Fine Particulate Matter Component Concentrations and Size Distributions Using SatelliteRetrieved Fractional Aerosol Optical Depth: Part 2-A Case Study, J. Air Waste Manage. Assoc., 57(11), 1360-1369, doi:10.3155/1047-3289.57.11.1360.

Jin, X., and T. Holloway (2015), Spatial and temporal variability of ozone sensitivity over China observed from the Ozone Monitoring Instrument, J. Geophys. Res. Atmos., 120, 7229-7246, doi:10.1002/2015JD023250.Received.

Kemball-Cook, S., G. Yarwood, J. Johnson, B. Dornblaser, and M. Estes (2015), Evaluating NOx emission inventories for regulatory air quality modeling using satellite and air quality model data, Atmos. Environ., 117, 1-8, doi:10.1016/j. atmosenv.2015.07.002.

King, M. D., et al. (2003), Cloud and serosol properties, precipitable water, and profiles of temperature and water vapor from MODIS, IEEE Trans. Geosci. Remote Sens., 41(2), 442-458.

Krotkov, N. A. et al. (2015), Aura OMI observations of regional SO2 and NO2 pollution changes from 2005 to 2014, Atmos. Chem. Phys. Disc., 15(19), 26555-26607, doi:10.5194/acpd-15-26555-2015.

Kumari, S., et al. (2013), Analysis of long-term ozone trend over Delhi and its meteorological adjustment, Int. J. Environ. Sci. Technol., 10, 1325-1336, doi:10.1007/s13762-012-0162-3. 
Lamsal, L. N., et al. (2010), Indirect validation of tropospheric nitrogen dioxide retrieved from the OMI satellite instrument: Insight into the seasonal variation of nitrogen oxides at northern midlatitudes, J. Geophys. Res. Atmos., 115(2), 1-15, doi:10.1029/2009JD013351.

Lamsal, L. N., et al. (2013), Scaling relationship for NO2 pollution and urban population size: a satellite perspective., Environ. Sci. Technol., 47(14), 7855-61.

Lamsal, L. N., et al. (2015), U.S. NO2 trends (2005-2013): EPAAir Quality System (AQS) data versus improved observations from the Ozone Monitoring Instrument (OMI), Atmos. Environ., 110(2), 130-143, doi:10.1016/j.atmosenv.2015.03.055.

Lu, Z., and D. G. Streets (2012), Increase in NOx Emissions from Indian Thermal Power Plants during 1996-2010: Unit-based Inventories and Multisatellite Observations, Env. Sci. Technol., 46, 7463-70.

Lu, Z., et al. (2013), Ozone Monitoring Instrument Observations of Interannual Increases in SO 2 Emissions from Indian CoalFired Power Plants during 2005 - 2012,

McDonald-Buller, E. C. et al. (2011), Establishing policy relevant background (PRB) ozone concentrations in the United States., Env. Sci. Technol., 45(22), 9484-97, doi:10.1021/es2022818.

Muntaseer Billah Ibn Azkar, M. A., et al. (2012), Simulation of urban and regional air pollution in Bangladesh, J. Geophys. Res. Atmos., 117(D7), n/a-n/a, doi:10.1029/2011JD016509.

National Aeronautics and Space Administration (2012), Ozone Monitoring Instrument (OMI) Data User's Guide.

National Ambient Air Quality Monitoring (2006), Air Quality Trends and Action Plan for Control of Air Pollution, Naaqms, (September), 5.

Oberman, J., E. Scotty, K. Maki, T. Holloway, and X. Jin (2014), Wisconsin Horizontal Interpolation Program for Contents v2.0.0 User Guide.

Pant, P., et al. (2015), Characterization of ambient PM2.5 at a pollution hotspot in New Delhi, India and inference of sources, Atmos. Environ., 109, 178-189, doi:10.1016/j.atmosenv.2015.02.074.

Streets, D. G. et al. (2013), Emissions estimation from satellite retrievals: A review of current capability, Atmos. Environ., 77, 1011-1042, doi:10.1016/j.atmosenv.2013.05.051.

Tong, D. Q., et al. (2015), Development of a windblown dust emission model FENGSHAA description and initial application in the United States, Rev.

World Health Organization (2014), Outdoor Air Pollution in the World Cities, Geneva, Switzerland.

Yarwood, G., S. Rao, M. Yocke, and G. Z. Whitten (2005), Updates to the Carbon Bond chemical mechanism: CB05 Final Report to the US EPA, RT-0400675.

Zhang, Y., et al. (2009), Probing into regional O 3 and particulate matter pollution in the United States: 2. An examination of formation mechanisms through a process analysis technique and sensitivity study, J. Geophys. Res., 114(D22), D22305, doi:10.1029/2009JD011900.

Zhao, T. X.-P., S. Ackerman, and W. Guo (2010), Dust and Smoke Detection for Multi-Channel Imagers, Remote Sens., 2(10), 2347-2368, doi:10.3390/rs2102347. 